University of Nebraska - Lincoln

DigitalCommons@University of Nebraska - Lincoln

\title{
Threadfin Shad Impacts Phytoplankton and Zooplankton Community Structures in Channel Catfish Ponds
}

\author{
Bartholomew W. Green \\ USDA ARS, bart.green@usda.gov \\ Peter Perschbacher \\ University of Arkansas at Pine Bluff \\ Gerald Ludwig \\ USDA, Agricultural Research Service \\ Sara E. Duke \\ USDA, Agricultural Research Service
}

Follow this and additional works at: https://digitalcommons.unl.edu/usdaarsfacpub

Part of the Agriculture Commons, and the Aquaculture and Fisheries Commons

Green, Bartholomew W.; Perschbacher, Peter; Ludwig, Gerald; and Duke, Sara E., "Threadfin Shad Impacts Phytoplankton and Zooplankton Community Structures in Channel Catfish Ponds" (2010). Publications from USDA-ARS / UNL Faculty. 2473.

https://digitalcommons.unl.edu/usdaarsfacpub/2473

This Article is brought to you for free and open access by the U.S. Department of Agriculture: Agricultural Research Service, Lincoln, Nebraska at DigitalCommons@University of Nebraska - Lincoln. It has been accepted for inclusion in Publications from USDA-ARS / UNL Faculty by an authorized administrator of DigitalCommons@University of Nebraska - Lincoln. 


\title{
Threadfin shad impacts phytoplankton and zooplankton community structures in channel catfish ponds
}

\author{
Bartholomew W Green', Peter Perschbacher ${ }^{2}$, Gerald Ludwig ${ }^{3}$ \& Sara E Duke \\ ${ }^{1}$ Aquaculture Systems Research Unit, USDA-ARS, Aquaculture/Fisheries Center, University of Arkansas at Pine Bluff, Pine \\ Bluff, AR, USA \\ ${ }^{2}$ Aquaculture/Fisheries Center, University of Arkansas at Pine Bluff, Pine Bluff, AR USA \\ ${ }^{3}$ Harry K. Dupree Stuttgart National Aquaculture Research Center, USDA-ARS, Stuttgart, AR, USA \\ ${ }^{4}$ Southern Plains Area Office, USDA-ARS, College Station,TX, USA
}

Correspondence: B W Green, USDA-ARS-SNARC, PO Box 1050, 2955 Highway 130 East, Stuttgart, AR 72160, USA. E-mail: bart.green@ ars.usda.gov

\begin{abstract}
Plankton community structure and chlorophyll $a$ concentration were compared in twelve 0.1 ha earthen ponds co-stocked with channel catfish (Ictalurus punctatus Rafinesque, 1818) in a multiple-batch culture (initial biomass $=5458 \mathrm{~kg} \mathrm{ha}^{-1}$ ) and a planktivore, threadfin shad (Dorosoma petenense Güther, 1867; initial biomass $=449 \mathrm{~kg} \mathrm{ha}^{-1}$ ), during the April-November growing season. We used a completely randomized design in a $2 \times 2$ factorial arrangement to test the planktivore level (presence or absence of threadfin shad) and channel catfish feeding frequency (daily or every third day). Channel catfish were fed a $32 \%$ protein feed to apparent satiation on days fed. The presence of threadfin shad affected phytoplankton and zooplankton community structure more than did feeding frequency, and the impact in ponds was more pronounced after 1 July. The numbers of all major groups of zooplankton were lower in ponds with threadfin shad, but were unaffected by the feeding frequency. Chlorophyll $a$ concentration before 1 July was higher in ponds with threadfin shad and unaffected by the feeding frequency, whereas after 1 July it was higher in ponds without threadfin shad and that were fed daily. Phytoplankton community structure after 1 July was dominated by nuisance algal bloom genera of cyanobacteria in ponds without threadfin shad and by Bacillariophyceae in ponds with threadfin shad.
\end{abstract}

Keywords: threadfin shad, channel catfish, phytoplankton, zooplankton, community structure, chlorophyll $a$

\section{Introduction}

Channel catfish (Ictalurus punctatus Rafinesque, 1818) typically are fed a $28-32 \%$ protein commercially formulated ration at rates as high as 80$120 \mathrm{~kg} \mathrm{ha}^{-1}$ day $^{-1}$ during the growing season. Much of the nitrogen and phosphorus in feed consumed by channel catfish is excreted (Boyd 1985) and results in high phytoplankton biomass (chlorophyll $a=200-600 \mathrm{mg} \mathrm{m}^{-3}$; Tucker \& Lloyd 1984; Tucker \& van der Ploeg 1993). This summertime algal community is often dominated by one to a few phytoplankton genera (Tucker \& Lloyd 1984). Sudden die-off of the algal bloom and inefficient oxygen production are two problems associated with high phytoplankton biomass (Smith 1988; Paerl \& Tucker 1995). Phytoplankton biomass in catfish ponds is generally unmanaged except where copper sulphate (an algicide) or diuron (a herbicide) is applied periodically to manage the incidence of off-flavour in fish, but neither chemical reduces phytoplankton biomass consistently during the summer months (Tucker, Hanson \& Kingsbury 2001; Zimba, Tucker, Mischke \& Grimm 2002). 
Cyanobacteria often dominate the phytoplankton community in catfish ponds during the summer months, and several cyanobacterial genera are responsible for the noxious algal blooms that occur (Paerl \& Tucker 1995). Additionally, there is a geographical variation in phytoplankton community structure thought to be caused by differences in source water quality (Hariyadi,Tucker, Steeby, van der Ploeg \& Boyd 1994). Chlorophyta and cyanobacteria are approximately co-dominant and comprise about $90 \%$ of the algal population in catfish ponds at Auburn, Alabama, during the summer and Boyd (1973) noted that algal populations were more diverse when Chlorophyta rather than cyanobacteria were dominant. Similar algal bloom composition is observed during the summer in ponds in west-central Alabama, but cyanobacteria can comprise $>50 \%$ of the algal population (Brown \& Boyd 1982; Armstrong, Boyd \& Lovell 1986). Cyanobacteria comprise $55-85 \%$ of the phytoplankton population during the summer in Mississippi catfish ponds (Tucker \& Lloyd 1984; Tucker \& van der Ploeg 1993). Source water for ponds has a low total alkalinity $\left(<20 \mathrm{mg} \mathrm{L}^{-1}\right.$ as $\left.\mathrm{CaCO}_{3}\right)$ in $\mathrm{Au}$ burn, Alabama, moderate total alkalinity (48$75 \mathrm{mg} \mathrm{L}^{-1}$ as $\mathrm{CaCO}_{3}$ ) in west-central Alabama, and moderately high total alkalinity $\left(250-350 \mathrm{mg} \mathrm{L}^{-1}\right.$ as $\mathrm{CaCO}_{3}$ ) in Mississippi.

Phytoplankton biomass can be regulated through bottom-up or top-down processes (McQueen, Post \& Mills 1986). In bottom-up control, the biomass of each successive trophic level is dependent upon the biomass of the trophic level that immediately precedes it. Reduction in exogenous nutrient loading, specifically phosphorus addition, is an example of bottomup control. However, restriction of nutrient inputs is an approach incompatible with intensively managed aquaculture ponds. In top-down control, a consumer at a superior trophic level controls the biomass of the trophic level immediately inferior to it. One approach to top-down control, known as biomanipulation theory, involves reducing the biomass of zooplanktivorous fish, which increases the abundance of large cladoceran zooplankton that reduce the phytoplankton biomass through grazing (Shapiro, Lamarra \& Lynch 1975). The trophic cascade theory, another approach to top-down control, predicts that the impact of a consumer will cascade to trophic levels lower than the one it impacts directly (Carpenter, Kitchell \& Hodgson 1985). Biomanipulation as a tool to reduce phytoplankton biomass in lakes continues to be researched (Lammens, Gulati, Meijer \& van Donk 1990; Hansson, Annadotter, Bergman, Hamrin,
Jeppesen, Kairesalo, Luokkanen, Nilsson, Søndergaard \& Strand 1998; Sierp, Qin \& Recknagel 2009).

Use of a planktivorous fish to reduce algae biomass in aquaculture ponds is of limited success and has only been attempted in channel catfish ponds only several times (Smith 1988). The mean chlorophyll $a$ concentration did not differ significantly in ponds stocked with channel catfish in a single-batch culture with and without threadfin shad (Dorosoma petenense Güther, 1867), likely because feed nutrients sustained high algal productivity (Lo Giudice, Bayne \& Popma 2004). Compared with channel catfish in monoculture, co-stocking blue tilapia (Oreochromis aureus Steindachner, 1864) with channel catfish significantly reduced zooplankton biomass but did not affect phytoplankton biomass (chlorophyll $a$ concentration; Torrans \& Lowell 1987). In contrast, the mean chlorophyll $a$ concentration was significantly higher in ponds co-stocked with channel catfish, channel $\times$ blue (Ictalurus furcatus Lesueur, 1840) hybrid catfish and a planktivorous fish compared with ponds with catfish only (Burke \& Bayne 1986; Burke, Bayne \& Rea 1986). Planktivorous fish tested were paddlefish (Polyodon spathula Walbaum, 1792), silver carp (Hypophthalmichthys molitrix Valenciennes, 1844) or bighead carp (Hepatica nobilis Richardson, 1845). The observed increase in chlorophyll $a$ concentration in these studies was attributed to a reduction in zooplankton biomass by planktivorous fish predation, which allowed phytoplankton biomass to increase.

Although attempts to reduce phytoplankton biomass in channel catfish ponds by co-stocking a plantivorous fish yielded mixed results, the co-stocked fish may alter the phytoplankton community structure and water quality in ways that could be beneficial. Lo Giudice et al. (2004) found that in ponds stocked with channel catfish in a single-batch culture the presence of threadfin shad resulted in significantly greater phytoplankton density, more taxa and smaller organisms. Additionally, they found that the mean total ammonia, nitrogen concentration was significantly lower in ponds stocked with threadfin shad. Many channel catfish farmers in west Alabama co-stock threadfin shad in their production ponds because they believe that doing so improves water quality (G. Whitis, Auburn University, pers. comm.). However, there are no reports in the scientific literature on the impact of threadfin shad on plankton communities in multiple-batch channel catfish ponds or in ponds with moderate total alkalinity and hardness. 
The objective of the present study was to determine the impact of threadfin shad on plankton communities in ponds with moderate total alkalinity water and stocked with channel catfish in multiplebatch production at rates that approximate fish biomass in commercial ponds at the start of the production season.

\section{Materials and methods}

Twelve 0.1 ha earthen ponds located on the Aquaculture Research Station, University of Arkansas at Pine Bluff, were used for this completely randomized design experiment in a $2 \times 2$ factorial arrangement. The factors were threadfin (presence or absence) shad and feeding frequency (daily or every third day). Ponds were treated with agricultural limestone (250 mesh, $1120 \mathrm{~kg} \mathrm{ha}^{-1}$ ) and then filled with ground water (total alkalinity $=52 \mathrm{mg} \mathrm{L}^{-1}$ as $\mathrm{CaCO}_{3}$; total hardness $=98 \mathrm{mgL}^{-1}$ as $\mathrm{CaCO}_{3}$ ) in mid-March, and a fertilization programme adapted from Ludwig, Stone and Collins (1998) was initiated. Cottonseed meal and 19-19-19 granular fertilizer, respectively, were added to each pond at 280 and $26 \mathrm{~kg} \mathrm{ha}^{-1}$ on 18 March, at 112 and $13 \mathrm{~kg} \mathrm{ha}^{-1}$ on 25 March, at 28 and $6.5 \mathrm{~kg} \mathrm{ha}^{-1}$ on 8 April and 22 April, at 56 and $13 \mathrm{~kg} \mathrm{ha}^{-1}$ on 29 April and at 56 and $6.5 \mathrm{~kg} \mathrm{ha}^{-1}$ on 8 May. The 19-19-19 fertilizer was dissolved in pond water before application.

Six of the ponds were randomly selected and were stocked incrementally from 22 April to 15 May with a total of $449 \pm 43 \mathrm{~kg} \mathrm{ha}^{-1}$ (mean $\pm \mathrm{SD}$ ) of prespawn, adult threadfin shad (here after referred to as shad when referring to our data). Poststocking mortality was observed in all ponds, especially after stocking the initial load of fish into ponds on 22-24 April. The initial load accounted for $56-70 \%$ of the total biomass of shad stocked. Low shad mortality was observed when the remaining loads of the fish were stocked because of improved transport and handling. The total recorded poststocking mortality of shad was $45 \pm 29 \mathrm{~kg} \mathrm{ha}^{-1}$. Thus, the estimated initial shad biomass was $404 \pm 20 \mathrm{~kg} \mathrm{ha}^{-1}$. At stocking, shad averaged $5.0 \mathrm{~g}$ and $7.8 \mathrm{~cm}$ total length. Stocking shad early was performed early to allow time for spawning.

All ponds were stocked from 29 May to 6 June with channel catfish at 5040 and $418 \mathrm{~kg} \mathrm{ha}^{-1}$ for stocker and fingerling catfish respectively. Stocker and fingerling catfish averaged 350 and $28 \mathrm{~g}_{\text {fish }}{ }^{-1}$, respectively, at stocking. Catfish were offered $32 \%$ protein floating extruded feed either daily or every third day. The feed treatment was assigned randomly to ponds with and without shad. Catfish were fed to apparent satiation (20-min period) at each feeding. During the experiment, catfish were fed a total of 119 and 43 days in the daily and every third-day feed treatments respectively. Because of disease outbreaks or sampling and harvesting activities, 20 days of feeding were missed in ponds fed daily and 5 days of feeding were missed in ponds fed every third day. The mean totals of 12453 and $4704 \mathrm{~kg} \mathrm{ha}^{-1}$ of feed were fed to catfish in the daily and every third-day feed treatments, respectively, during the 144 day catfish culture period. The mean daily feed rates were 104 and $112 \mathrm{~kg} \mathrm{ha}^{-1}$ day $^{-1}$ for the daily and every third-day feed treatments, respectively, and the respective maximum daily feed rates were 233 and $200 \mathrm{~kg} \mathrm{ha}^{-1}$ day $^{-1}$.

Pond dissolved oxygen (DO) concentration and temperature were monitored daily through June in the morning (ca. 07:00 hours) and afternoon (ca. 14:00 hours) using a DO meter (Model 550A, Yellow Springs Instruments, Yellow Springs, OH, USA) and continuously beginning in July by a galvanic oxygen sensor and thermistor connected to a datalogger (Model CR205, Campbell Scientific, Logan, UT, USA). An electric paddlewheel aerator $(0.373 \mathrm{~kW})$ operated nightly in ponds from April to June, and beginning in July was activated by the datalogger when the pond DO concentration declined below $3.5 \mathrm{mg} \mathrm{L}^{-1}$.

A $1.27 \mathrm{~cm}$ square mesh seine, the smallest mesh size available to us, was used initially to harvest fish from ponds from 20 to 23 October. However, hundreds of shad became gilled in the seine net during each of the first two seine hauls attempted. The time required to remove the gilled shad manually from the seine jeopardized the survival of the landed catfish. Manual removal of gilled shad often resulted in physical mutilation of the fish, which limited the data that could be collected. Thus, we decided to complete the harvest using a $2.54 \mathrm{~cm}$ square mesh seine, through which shad passed. In doing this, it was possible to recover only a portion of the shad population in the pond. Each pond was drained and scrapped following seining. Means 25.7 and $21.8 \mathrm{~kg} \mathrm{ha}^{-1}$ of shad were recovered at harvest from shad-daily feed and shad-every third-day feed treatment ponds respectively. We observed shad (ca. $2.5-15.0 \mathrm{~cm} \mathrm{TL}$ ) trapped in the mud of all shad ponds at draining and estimated that their relative abundance was common. An unknown number of shad were trapped in the pond mud, but not visible. Thus, we were unable to 
quantify the total shad biomass at harvest. Catfish production data were reported separately (Green, Perschbacher \& Ludwig 2009).

Pond water samples were analysed weekly for chlorophyll $a$ using the chloroform-methanol extraction method (Lloyd \& Tucker 1988). A minimum of four $90 \mathrm{~cm}$ water column samples (Boyd 1979) were collected per pond, pooled and a $0.5 \mathrm{~L}$ sub-sample was taken for analysis. Water samples were stored on ice in an opaque cooler until analysis, which began within $2 \mathrm{~h}$ of sample collection.

Pond phytoplankton samples were enumerated on a weekly to biweekly basis. A $100 \mathrm{~mL}$ aliquot was taken from the water sample collected for chlorophyll $a$, fixed with Lugol's solution and sedimented in a $100 \mathrm{~mL}$ graduated cylinder for 1 week (Clesceri, Greenberg \& Eaton 1998). If surface floating algae were encountered, detergent was added to facilitate settling. The upper 50-65 mL was decanted from the graduated cylinder and the settled algae were preserved with formalin. Identification and counting was performed on a $1 \mathrm{~mL}$ sample in a Sedgwick-Rafter counting cell using $\times 150$ magnification and a Whipple grid. The numbers of unicells, colonies and trichomes were counted in 10 grids per cell in all quadrants. Phytoplankton identification was to genera, with the exception of Cyanobacteria, which were identified to species based on the descriptions provided in Cocke (1967) with additional reference to Desikachary (1959). Based on the counts and the final volume, phytoplankton numbers per millilitre were determined.

Pond zooplankton populations were sampled at 24-week intervals from 21 April to 15 October. Zooplankton samples were collected in the morning in each pond by slowly lifting an $80 \mu \mathrm{m}$ Wisconsin plankton net through a vertical distance that encompassed $10 \mathrm{~L}$ of water. This procedure was followed three times on three sides of the pond. The three samples were combined into a single sample jar and preserved in $70 \%$ isopropyl alcohol. Major categories of zooplankton (cladocerans, copepods, copepod nauplii, rotifers) were identified and counted using a $\times 40-100$ microscope and a $1 \mathrm{~mL}$ Sedgwick-Rafter counting cell.

Datasets were analysed using the generalized linear mixed models and the mixed models procedures of SAS version 9.1 (SAS Institute, Cary, NC, USA). In the statistical models, individual plankton group or chlorophyll $a$ concentration was the dependent variable and the presence of shad and feeding frequency were the independent variables and pond was a random effect. Data were analysed for the entire experiment and by season because we observed a shift in community structure around 1 July. In the latter data analyses, a dummy variable (season) was defined to identify the early and late seasons, before and after 1 July respectively. Phytoplankton and zooplankton count data were $\log _{10}$-transformed for data analysis because of the high variability among individual data points and to ensure that the residuals met the assumptions of the analysis; the constant, 1, was added to each data point before $\log _{10}$-transformation to ensure that the transformation was defined. Differences were considered to be significant at $\alpha=0.05$.

\section{Results}

Zooplankton population composition varied throughout the season, and treatment effects were evident (Figs 1 and 2). Mean abundance (number $\mathrm{L}^{-1}$ ) of rotifers, cladocerans, copepods and nauplii over the course of the entire experiment was significantly lower in shad ponds, but was not affected by the feeding frequency. The shad $\times$ feeding frequency treatment interaction was significant only for rotifers; rotifer abundance in ponds where fish were fed daily was significantly greater in ponds without shad, but was not affected by the presence of shad in ponds where fish were fed every third day.

The mean zooplankton counts during both seasons were affected by the presence of threadfin shad, but not by the feeding frequency (Table 1). There was a significant treatment interaction only for rotifer abundance during the late season; the feeding frequency in shad ponds did not affect the mean rotifer abundance, whereas in ponds without shad rotifer abundance was significantly greater where fish were fed daily.

The chlorophyll a concentration in ponds increased rapidly soon after feeding of catfish was initiated (Fig. 3). The chlorophyll $a$ concentration over the entire experiment was not affected by shad, and averaged 202 and $222 \mathrm{mg} \mathrm{m}^{-3}$ where shad were present or absent respectively. The feeding frequency affected the chlorophyll $a$ concentration significantly, which averaged 242 and $181 \mathrm{mg} \mathrm{m}^{-3}$ where feed was offered daily or every third day respectively. There was a significant treatment interaction for the mean chlorophyll a concentration: the mean chlorophyll $a$ concentration in shad ponds did not differ with feeding frequency, whereas in ponds without 
$\square$ No Shad — Shad

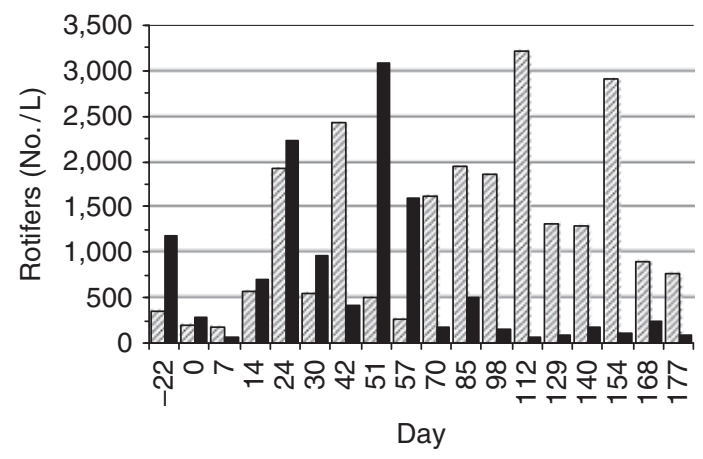

$\square$ No Shad @ Shad

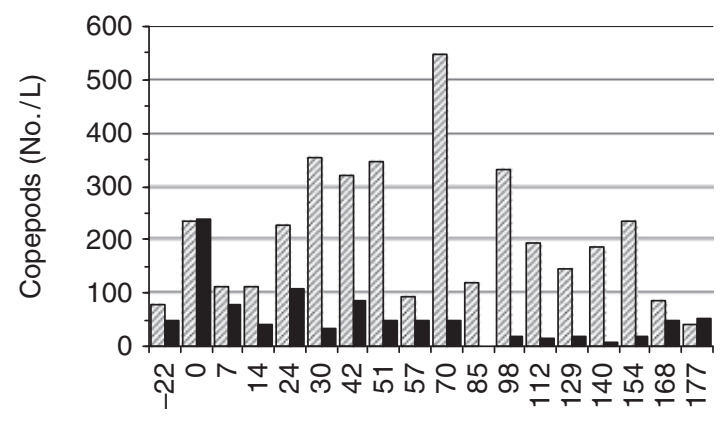

Day
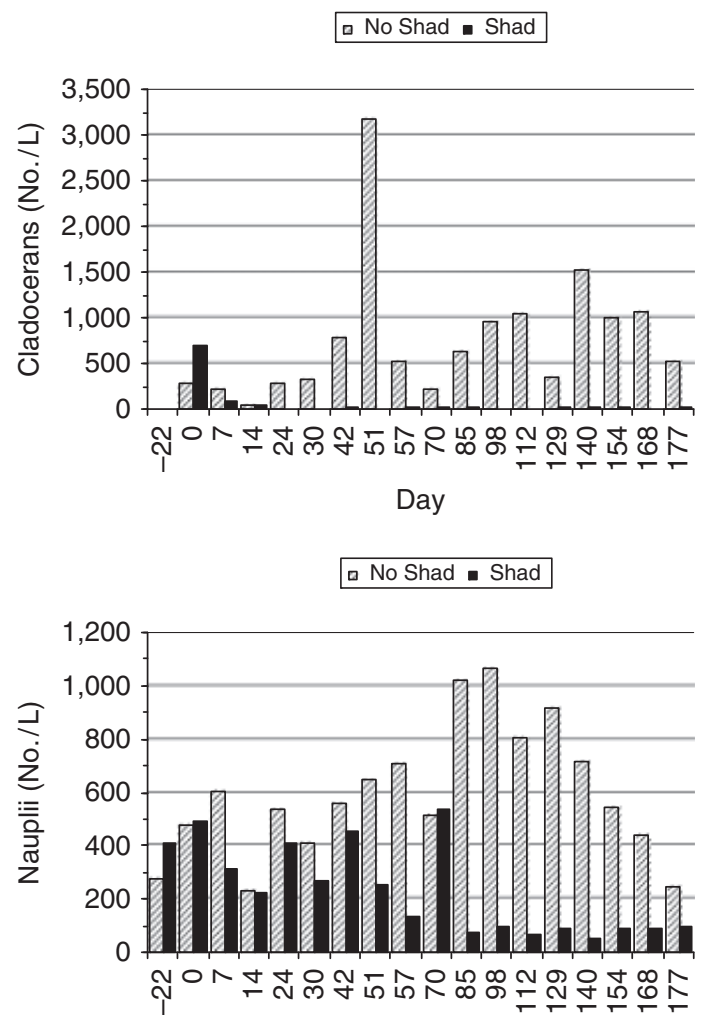

Day

Figure 1 Mean zooplankton counts by a major group in a multiple-batch channel catfish ponds where fish are fed daily and threadfin shad are present or absent. Day 22 corresponds to 31 March, the date on which filling of ponds was completed. Day 0 corresponds to 22 April, the date on which threadfin shad were stocked in ponds. Catfish were stocked on 29 May (day 38).

shad mean chlorophyll $a$ concentration was significantly greater when fish were fed daily.

The mean chlorophyll $a$ concentration during the early (April-June) season was significantly greater in ponds with shad $\left(203 \mathrm{mg} \mathrm{m}^{-3}\right)$ than in ponds without shad $\left(139 \mathrm{mg} \mathrm{m}^{-3}\right)$, but did not differ between feeding frequencies (Table 1). The presence of shad did not affect the chlorophyll $a$ concentration significantly where fish were fed daily, but did so where fish were fed every third day. During the late (July-October) season, the mean chlorophyll $a$ concentration was significantly greater in ponds without shad $\left(293 \mathrm{mg} \mathrm{m}^{-3}\right.$ ) compared with those with shad $\left(201 \mathrm{mg} \mathrm{m}^{-3}\right)$, and in ponds where fish were fed daily $\left(288 \mathrm{mg} \mathrm{m}^{-3}\right)$ compared with every third day (205 $\mathrm{mg} \mathrm{m}^{-3}$; Table 1). The mean chlorophyll $a$ concentration in shad ponds did not differ between the daily and every third-day feed treatments, and in ponds without shad was significantly greater when fish were fed daily.
Phytoplankton population composition varied throughout the season (Fig. 4), and treatment effects were detected for the entire season. The counts of cyanobacteria colonies and trichomes were significantly greater in ponds without shad, whereas the counts of Cryptophyta, Bacillariophyta, Chlorophyta colonies and Euglenophyta were significantly greater in shad ponds. Only the Chlorophyta colony and Euglenophyta counts differed in response to feeding frequency and were significantly greater in the daily feed treatment. No significant interaction between main effects was detected for any taxonomic group.

Phytoplankton counts were affected more by the presence of threadfin shad than by feeding frequency. Treatment effects during the early season were observed only for a small number of taxonomic groups (Table 1). Chlorophyta colony, Euglenophyta and Cryptophyta counts were significantly greater in shad ponds. During the late season, cyanobacteria colonies and trichomes, and Chlorophyta unicells 

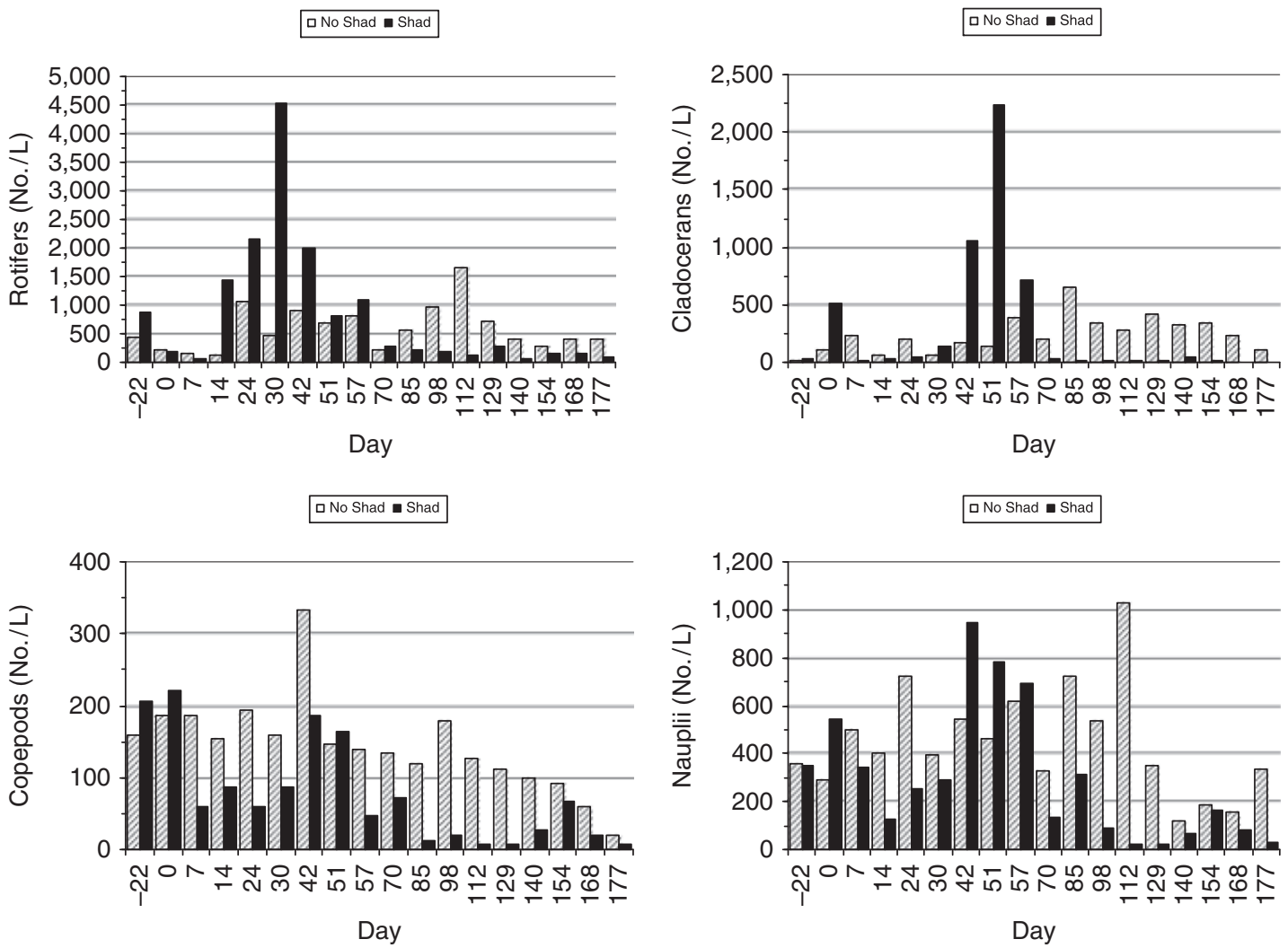

Figure 2 Mean zooplankton counts by major group in a multiple-batch channel catfish ponds where fish are fed every third day and threadfin shad are present or absent. Day 22 corresponds to $31 \mathrm{March}$, the date on which filling of ponds was completed. Day 0 corresponds to 22 April, the date on which threadfin shad were stocked in ponds. Catfish were stocked on 29 May (day 38).

had significantly higher counts in ponds without shad. In ponds with shad, Bacillariophyta counts were significantly higher, and counts of Chlorophyta colonies and Euglenophyta were significantly greater in the daily feed treatment ponds.

Cyanobacteria known to produce off-flavour compounds were identified in low numbers in ponds (Fig. 4). The mean counts of Anabaena spp. during the early season were 1 and $2 \mathrm{~mL}^{-1}$ in ponds with and without shad, respectively, and 2 and $1 \mathrm{~mL}^{-1}$ in ponds where fish were fed daily or every third day respectively. No Anabaena spp. were detected during the late season. There were no significant treatment effects or interaction during either season. Anabaena circinalis counts in ponds with and without shad, respectively, averaged 0 and $1 \mathrm{~mL}^{-1}$ and 0 and $5 \mathrm{~mL}^{-1}$ during the early and late seasons respectively. In ponds where fish were fed daily or every third day, respectively, the mean counts were 1 and $3 \mathrm{~mL}^{-1}$ during the late season; $A$. circinalis was not detected during the early season. No treatment effects or interaction were noted. Planktothrix peronata (Oscillatoria cf. chalybea) were detected only during the late season and counts averaged 0 and $53 \mathrm{~mL}^{-1}$ in ponds with and without shad, respectively, and 10 and $5 \mathrm{~mL}^{-1}$ in ponds where fish were fed daily or every third day respectively. The mean counts differed significantly only for the shad treatment.

The mean daily DO concentration during the late season was not affected by the presence of threadfin shad $\left(\right.$ mean $=4.8 \mathrm{mg} \mathrm{L}^{-1}$ ), but was significantly lower in ponds where fish were fed daily $\left(4.3 \mathrm{mg} \mathrm{L}^{-1}\right)$ compared with every third day $\left(5.2 \mathrm{mg} \mathrm{L}^{-1}\right)$. The interaction between main effects was not significant. In contrast, the mean daily minimum DO concentration was significantly lower in ponds without shad $\left(2.7 \mathrm{mg} \mathrm{L}^{-1}\right)$ compared with ponds with shad (3.1 $\mathrm{m} \mathrm{L} \mathrm{L}^{-1}$ ), and significantly lower in ponds where fish were fed daily $\left(2.5 \mathrm{mg} \mathrm{L}^{-1}\right)$ compared with every third day $\left(3.3 \mathrm{mg} \mathrm{L}^{-1}\right)$. In ponds where fish were fed 
Table 1 Least squares means and pooled SE for chlorophyll $a$ concentration $\left(\mathrm{mg} \mathrm{m}^{-3}\right)$, and back-transformed $\left(\operatorname{anti}^{-} \log _{10}\right)$ phytoplankton (number $\mathrm{mL}^{-1}$ ) and zooplankton (number $\mathrm{L}^{-1}$ ) abundance for main effects and interaction during the April-June (early) and July-October (late) periods of a 177-day experiment in 0.1 ha earthen ponds where channel catfish in multiplebatch culture were fed daily or every third day and threadfin shad were present or absent. Pooled SE for phytoplankton and zooplankton data are not back-transformed and $P$ values are for analysis of $\log _{10}$-transformed data

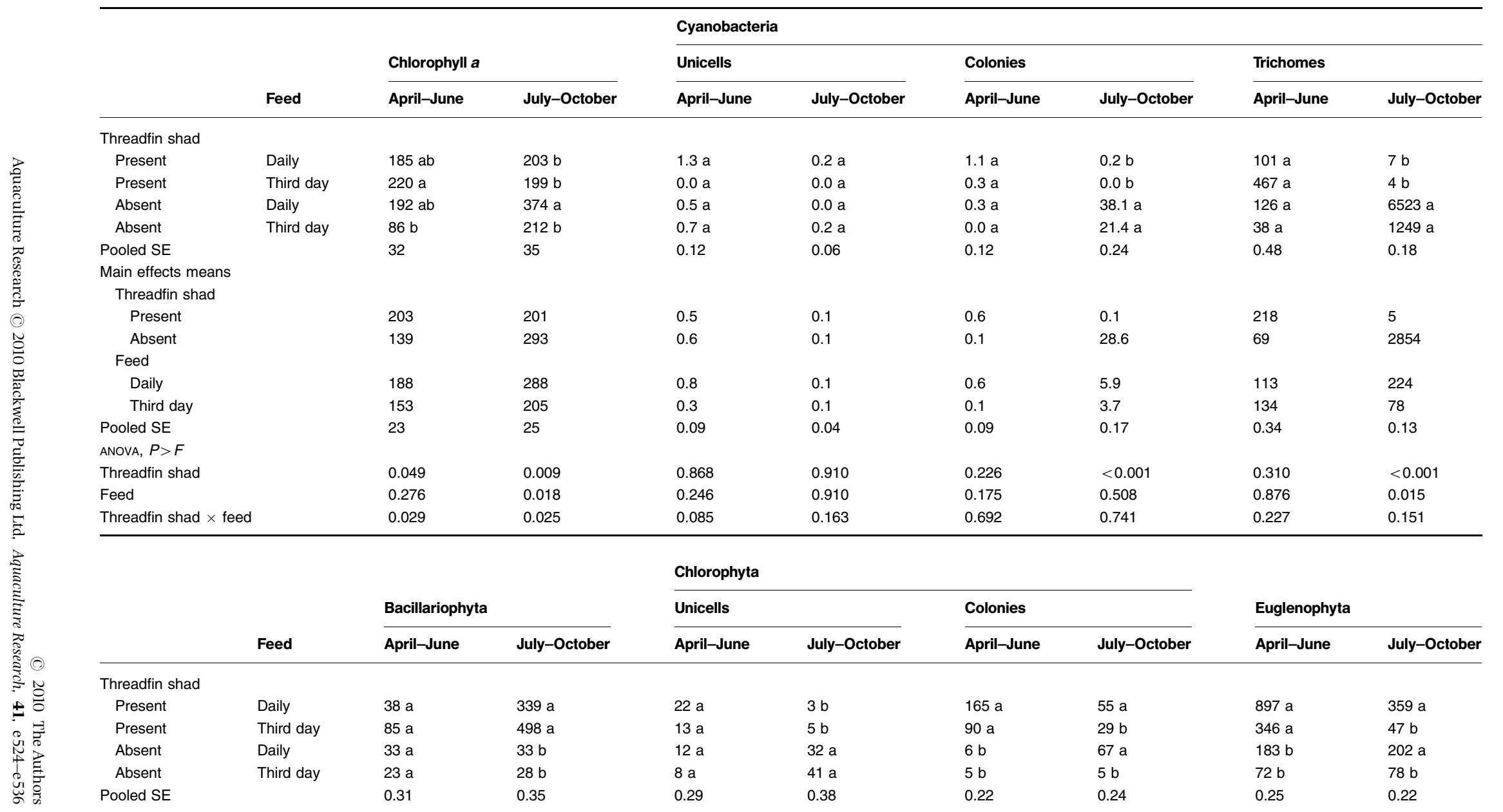


Table 1 continued

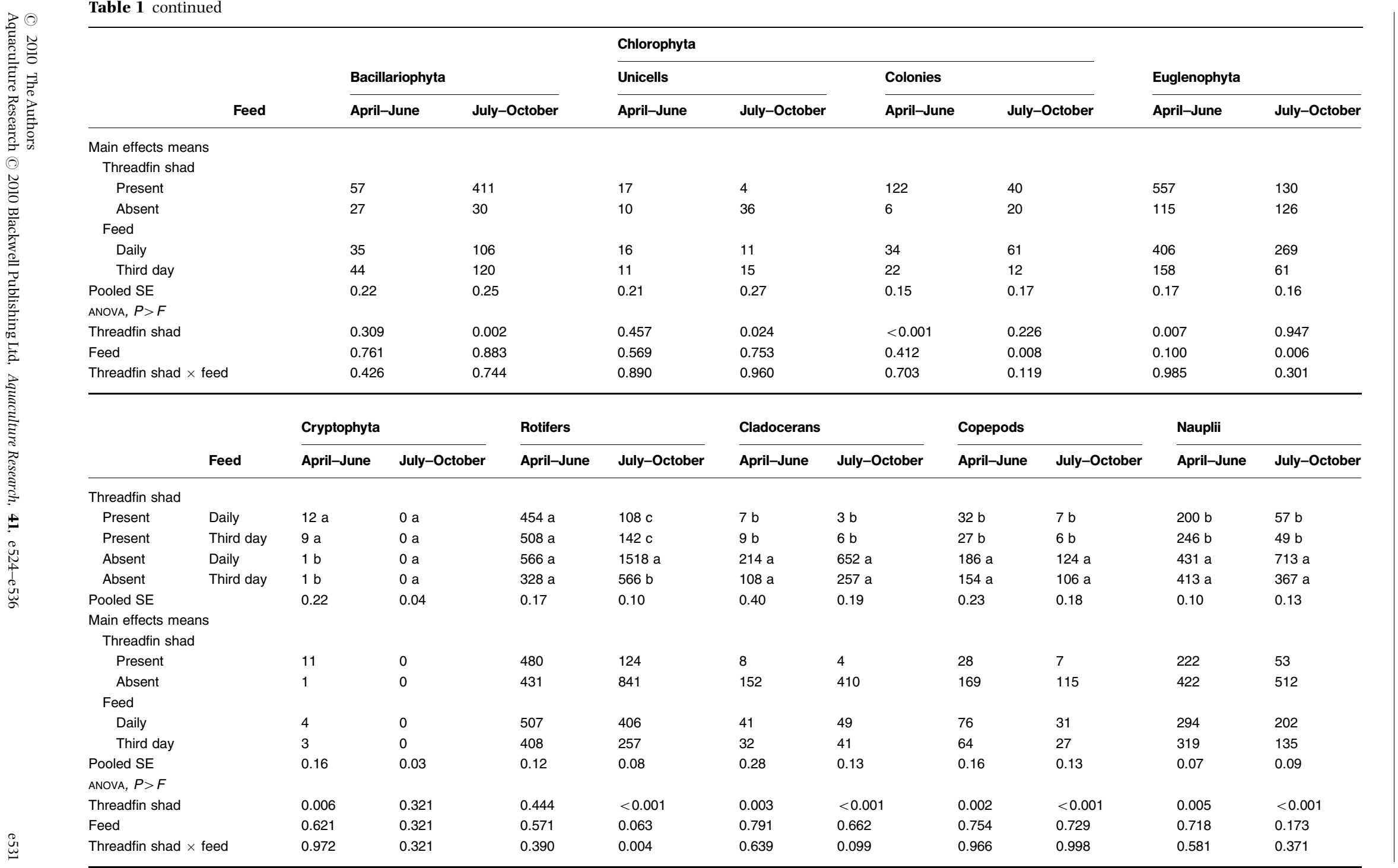

Means in columns followed by the same letter do not differ significantly. 

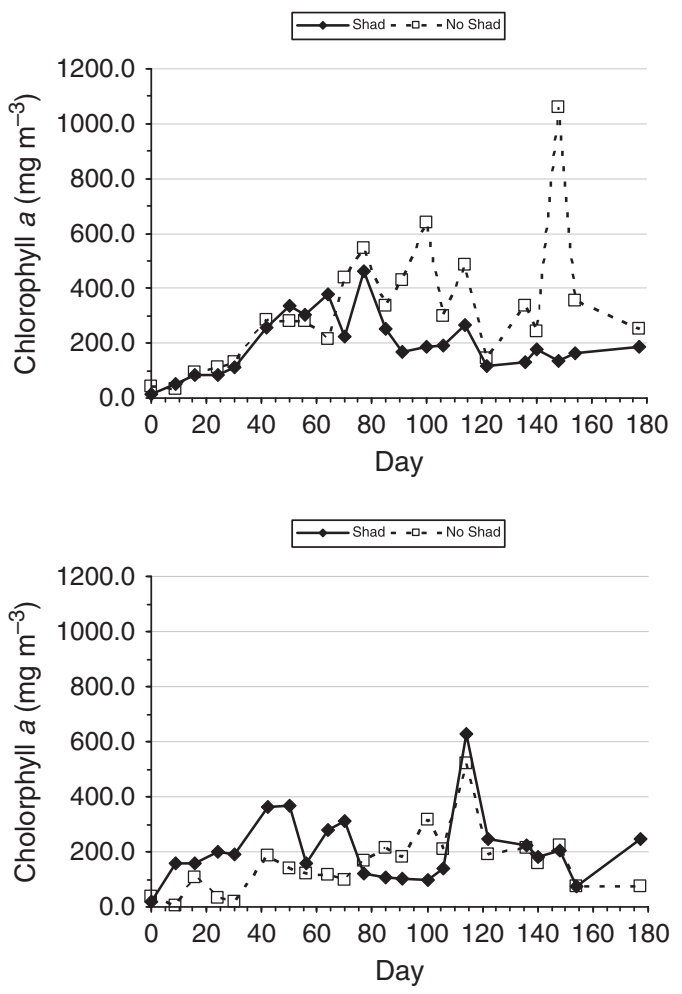

Figure 3 Mean chlorophyll $a$ concentrations in ponds where channel catfish in a multiple-batch culture are fed daily (above) or every third day (below) and threadfin shad are present or absent. Day 0 corresponds to 22 April, the date on which threadfin shad were stocked in ponds. Catfish were stocked on 29 May (day 38).

daily, the mean minimum DO was significantly higher lower where shad were absent $\left(2.1 \mathrm{mg} \mathrm{L}^{-1}\right)$ compared with present $\left(2.9 \mathrm{mg} \mathrm{L}^{-1}\right)$. The mean daily minimum DO concentration in ponds where fish were fed every third day did not differ with shad presence or absence and averaged 3.3 and $3.3 \mathrm{mg} \mathrm{L}^{-1}$ respectively. The mean daily minimum DO concentration decreased as mean chlorophyll $a$ concentration increased $\left(R^{2}=0.578\right)$. No relationship was observed between the mean daily DO and chlorophyll a. Significantly more total hours of nightly aeration were required during the late season in ponds where fish were fed daily $(451 \mathrm{~h})$ compared with every third day $(204 \mathrm{~h})$. The total hours of nightly aeration were not affected by the presence of shad $($ mean $=328 \mathrm{~h}$ ) and there was no interaction between the main effects. Early season DO concentrations were not analysed statistically because the two daily readings were not taken at precisely the same time each day.

\section{Discussion}

The impact of threadfin shad on the phytoplankton and zooplankton populations in the present experiment was expressed differentially and was greater during the late season (after 1 July). Feeding frequency, i.e., nutrient input, was of secondary importance to plankton population dynamics.

The survival of larval threadfin shad is positively correlated with the water temperature at hatching over the range $17-28^{\circ} \mathrm{C}$, with survival uniformly high $(>80 \%)$ at water temperature $>24^{\circ} \mathrm{C}$ when prey density (rotifers and copepod nauplii) exceeds 160 organisms L ${ }^{-1}$ (Betsill \& Van Den Avyle 1997). Threadfin shad are known to spawn in ponds and reservoirs from May to August (Swingle 1969; Kuklinski 2006). In the present experiment, water temperature was $\geq 20{ }^{\circ} \mathrm{C}$ in late April when threadfin shad were stocked and averaged 30.1 and $30.2^{\circ} \mathrm{C}$ in July and $\mathrm{Au}$ gust respectively. The mean water temperature ranged from 26 to $27^{\circ} \mathrm{C}$ during the second and third weeks of June, and the mean abundance of rotifers and copepod nauplii both exceeded 160 organisms $\mathrm{L}^{-1}$ during this period.

Threadfin shad reduced the early season mean abundance of all major zooplankton groups except rotifers and this suppression extended to all major groups throughout the late season. The impact of threadfin shad on zooplankton populations was apparent within 1-2 weeks of stocking. The substantial reduction we observed in zooplankton abundance corresponded closely to the expected peak in threadfin shad spawning during May and June. Our results concur with those of Guest, Drenner, Threlkeld, Martin and Smith (1990), who found that zooplankton abundance declined during the period threadfin shad were spawning and remained low during the postspawning period.

Threadfin shad essentially suppress cladoceran and copepod zooplankton, substantially reduce copepod nauplii abundance, and moderately reduce rotifer abundance (Guest et al. 1990; Baca \& Drenner 1995). Feeding frequency did not affect zooplankton abundance in the present experiment. Only during the late season did we detect a significant interaction between the main effects, but only for rotifer abundance. This nutrient-related interaction resulted from the significantly higher chlorophyll $a$ concentration in ponds without shad where fish were fed daily compared with every third day. Baca and Drenner (1995) found that the abundance of all major zooplankton groups was significantly greater in high 

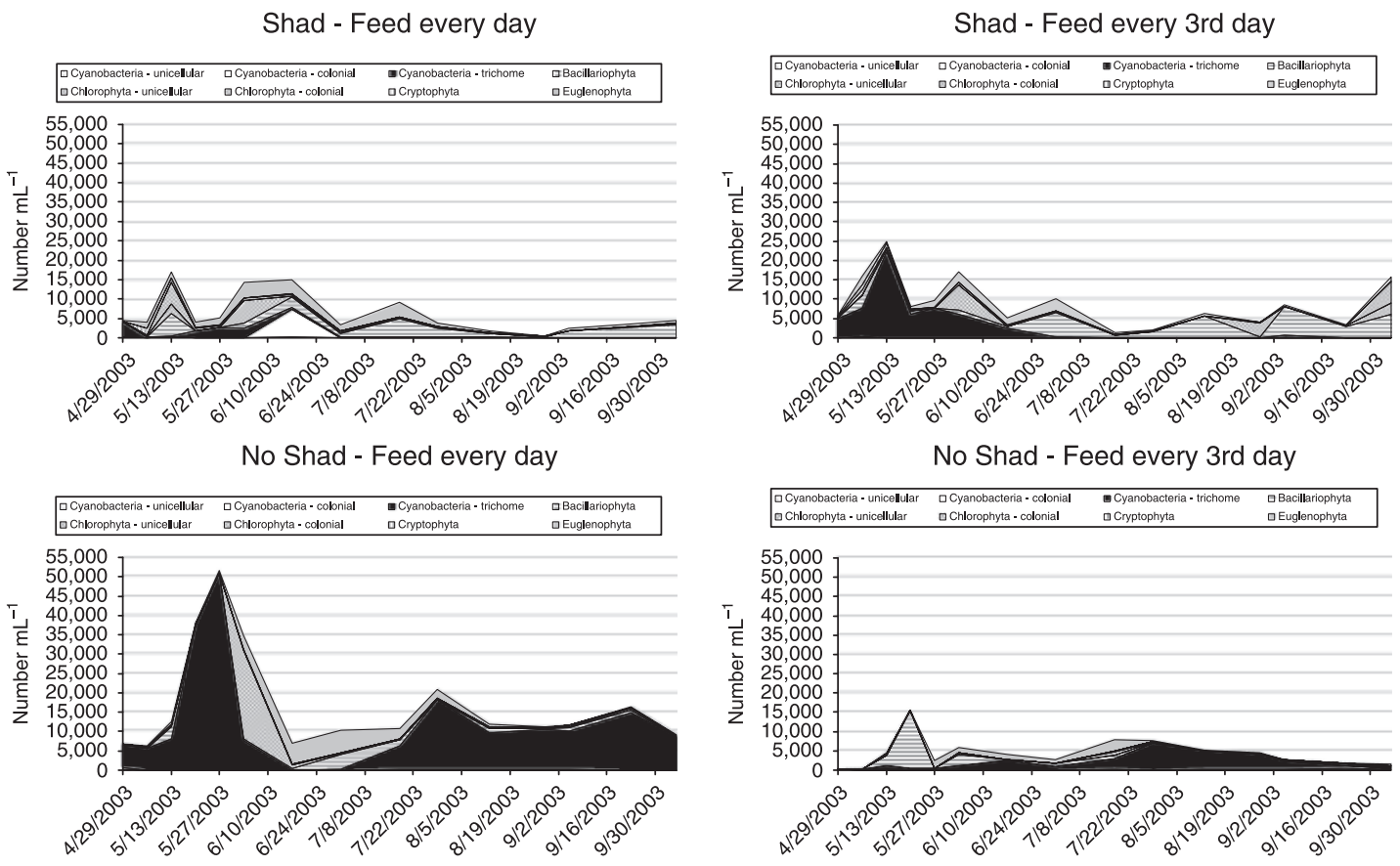

Figure 4 Mean phytoplankton population composition by functional group in ponds where channel catfish in a multiple-batch culture are fed daily or every third day and threadfin shad are present (above) or absent (below). Day 0 corresponds to 22 April, the date on which threadfin shad were stocked in ponds. Catfish were stocked on 29 May (day 38).

compared with low phosphorus addition treatments in the absence of threadfin shad, and the observed treatment interaction for cladocerans and copepods resulted from their greater abundance in the highphosphorus no-shad treatment. Our waters were considerably more eutrophic, based on chlorophyll $a$ concentration, than those of Baca and Drenner (1995).

The mean chlorophyll $a$ concentration over the entire experiment was unaffected by threadfin shad. Once channel catfish were stocked into ponds, chlorophyll $a$ concentrations remained high, likely in response to regular nutrient inputs as feed. The significantly greater chlorophyll $a$ concentration in ponds fed daily compared with every third day was expected. However, it was more meaningful to evaluate chlorophyll $a$ concentration before and after 1 July (early and late seasons) because of the incremental effect of shad and increasing daily feed ration. During the early season, the significant shad $\times$ feeding frequency interaction showed that the main effects were not independent. Nutrient input in ponds where fish were fed daily was sufficient to mitigate the impact of threadfin shad. However, when fish were fed every third day, nutrient input was lower and shad predation of zooplankton resulted in increased phytoplankton biomass. This is consistent with the biomanipulation theory (Shapiro et al. 1975), but because we did not measure zooplankton size we are unable to determine the relative role of zooplankton grazing and nutrient regeneration by threadfin shad.

The significant shad $\times$ feeding frequency interaction for chlorophyll $a$ concentration during the late season showed that the main effects were not independent. In ponds where fish were fed every third day, chlorophyll $a$ concentration was not affected by threadfin shad, whereas when fish were fed daily chlorophyll $a$ concentration was greater in ponds without shad. The significant reduction in chlorophyll $a$ concentration in the presence of threadfin shad was in contrast to the outcomes predicted by the biomanipulation or trophic cascade theories. The bottom-up:top-down model (McQueen et al. 1986) may explain what we observed in these eutrophic ponds, but we lack data on the zooplankton biomass and nutrient concentrations needed to apply this model. Another explanation was that nuisance genera of cyanobacteria predominated in ponds without shad and Bacillariophyceae predominated in ponds with shad during the late season. Colonial and filamentous cyanobacteria have a higher chlorophyll $a$ content than smaller unicellular algae. Lo 
Giudice et al. (2004) reported that the mean chlorophyll $a$ concentration did not differ significantly in ponds stocked with channel catfish in a single-batch culture with and without threadfin shad, likely because feed nutrients sustained high algal productivity. Similarly, Baca and Drenner (1995) found that with high phosphorus addition, the chlorophyll $a$ concentration was not affected by the presence of threadfin shad.

Phytoplankton community composition shifted from cyanobacteria to Bacilliophyceae dominance and the total phytoplankton count was reduced significantly by the presence of threadfin shad. Anabaena, Aphanizomenon, Oscillatoria and Microcystis are among a subset of cyanobacterial genera responsible for nuisance algal blooms in aquaculture ponds (Paerl \& Tucker 1995) and are poorly assimilated by zooplankton (Paerl 1988). During the late season, these genera comprised $53-60 \%$ of the total phytoplankton abundance in ponds without threadfin shad, whereas they comprised $2-3 \%$ of the total phytoplankton abundance in ponds with shad. Oscillatoria was the predominant nuisance algal bloom genera in our ponds and is common during the summer in commercial catfish ponds in Mississippi (Tucker \& Lloyd 1984; van der Ploeg \& Tucker 1993). Off-flavour producing cyanobacteria were included in the overall reduction in cyanobacteria observed in ponds with shad. While the abundance of off-flavour producing cyanobacteria was low in all treatments throughout the experiment, we did not quantify geosmin or 2-methylisoborneol in fish; this should be done in future experiments. Threadfin shad predation during the present experiment reduced zooplankton numbers and the reduced zooplankton grazing pressure on smaller phytoplankters allowed the shift in phytoplankton community structure. Reduction in the zooplankton by planktivore grazing can change the phytoplankton community structure but may not necessarily reduce chlorophyll $a$ concentration (e.g., Drenner, Taylor, Lazzaro \& Kettle 1984; Drenner,Threlkeld \& McCracken 1986; Lazzaro, Drenner, Stein \& smith 1992; Ramcharan, France \& McQueen 1996).

In a study where threadfin shad were co-stocked with channel catfish in a single-batch culture, Lo Giudice et al. (2004) reported that dominance of the phytoplankton community was unaltered by the presence of threadfin shad and remained at $62-67 \%$ Chlorophyta and $17-20 \%$ cyanobacteria in the treatment and control ponds. They also found that the phytoplankton density and number of genera increased significantly and the greatest axial linear diameter of phytoplankton decreased significantly when threadfin shad were present. The difference between our results and those of Lo Giudice et al. (2004) likely relate to the production system and the total feed application as well as the geographical differences observed by Hariyadi et al. (1994). We used a multiple-batch production system and our mean initial fish biomass ( $5458 \mathrm{~kg} \mathrm{ha}^{-1}$ ) and total feed application $\left(12453 \mathrm{~kg} \mathrm{ha}^{-1}\right)$ exceeded the mean channel catfish production $\left(4781 \mathrm{~kg} \mathrm{ha}^{-1}\right)$ and total feed application (6375 $\mathrm{kg} \mathrm{ha}^{-1}$ ) reported by Lo Giudice et al. (2004). Phytoplankton biomass, as indicated by chlorophyll $a$ concentration, increased to high levels soon after channel catfish were stocked in the present experiment because of high feeding rates. The initial feeding rates in Lo Giudice et al. (2004) likely were low because the initial channel catfish biomass was low (136 kg ha ${ }^{-1}$ ). Consequently, phytoplankton biomass, as indicated by chlorophyll $a$ concentration, increased slowly and phytoplankton population dynamics in their ponds would be expected to differ from those observed in the present experiment.

High feeding rates in catfish ponds during the summer cause high phytoplankton biomass, which often results in low early morning DO concentrations despite the use of mechanical aeration (Hargreaves \& Steeby 1999). The significant treatment interaction for the minimum daily DO concentration was another manifestation of the effect of threadfin shad in ponds where fish were fed daily. The high phytoplankton biomass in ponds without shad where fish were fed daily was dominated by nuisance bloom genera of cyanobacteria, which are known to be less efficient oxygen producers (Paerl \& Tucker 1995). Channel catfish growth is affected negatively by the minimum DO concentration they experience on a daily basis (Torrans 2008). However, the improvement in the DO regime in ponds with shad where fish were fed daily did not translate into improved net fish yield (Green et al. 2009).

In summary, threadfin shad, at the stocking rate used in this experiment, reduced zooplankton abundance. The reduction in zooplankton grazing of phytoplankton caused the phytoplankton population composition to shift from dominance by nuisance bloom genera of cyanobacteria to Bacillariophyceae after 1 July. Chlorophyll $a$ concentration was reduced, but ponds remained eutrophic. Additional research on the effect of threadfin shad stocking rate on phytoplankton population composition and geosmin and MIB concentrations is needed and may provide a 
management strategy for managing nuisance bloom genera of cyanobacteria in channel catfish ponds.

\section{Acknowledgments}

The ARS and UAPB Aquaculture Research Station support personnel are thanked for their assistance during this study. We thank Jason Brown for analysing the zooplankton samples. We thank Steve Lewis and colleagues at the Arkansas Game and Fish commission for providing threadfin shad. The mention of trade names or commercial products is solely for the purpose of providing specific information and does not imply recommendation or endorsement by the US Department of Agriculture.

\section{References}

Armstrong M.S., Boyd C.E. \& Lovell R.T. (1986) Environmental factors affecting flavor of channel catfish from production ponds. Progressive Fish-Culturist 48, 113-119.

Baca R.M. \& Drenner R.W. (1995) Do the effects of piscivorous largemouth bass cascade to the plankton? Hydrobiologia 316, 139-151.

Betsill R.K. \& Van Den Avyle M.J. (1997) Effect of temperature and zooplankton abundance on growth and survival of larval threadfin shad. Transactions of the American Fisheries Society 126, 999-1011.

Boyd C.E. (1973) Summer algal communities and primary productivity in fish ponds. Hydrobiologia 41, 357-390.

Boyd C.E. (1979) Water Quality inWarmwater Fish Ponds. Alabama Agricultural Experiment Station, Auburn University, Auburn, AL, USA.

Boyd C.E. (1985) Chemical budgets for catfish ponds. Transactions of the American Fisheries Society 114, 291-298.

Brown S.W. \& Boyd C.E. (1982) Off-flavor in channel catfish from commercial ponds. Transactions of the American Fisheries Society 111, 379-383.

Burke J.S. \& Bayne D.R. (1986) Impact of paddlefish on plankton and water quality of catfish ponds. Progressive FishCulturist 48, 177-183.

Burke J.S., Bayne D.R. \& Rea H. (1986) Impact of silver and bighead carps on plankton communities of channel catfish ponds. Aquaculture 55, 59-68.

Carpenter S.R., Kitchell J.F. \& Hodgson J.R. (1985) Cascading trophic interactions and lake productivity. BioScience $\mathbf{3 5}$, 634-639.

Clesceri L.S., Greenberg A.E. \& Eaton A.D. (Eds.) (1998) Standard Methods for the Examination of Water and Wastewater, 20th edn. American Public Health Association, American Water Works Association, and Water Environment Federation, Washington, DC, USA.
Cocke E.C. (1967) The Myxophyceae of North Carolina. Edwards Brothers, Ann Arbor, MI, USA.

Desikachary T.V. (1959) Cyanophyta. Indian Council of Agricultural Research, New Delhi, India.

Drenner R.W., Taylor S.B., Lazzaro X. \& Kettle D. (1984) Particle-grazing and plankton community impact of an omnivorous cichlid. Transactions of the American Fisheries Society 113, 397-402.

Drenner R.W., Threlkeld S.T. \& McCracken M.D. (1986) Experimental analysis of the direct and indirect effects of an omnivorous filter-feeding clupeid on plankton community structure. Canadian Journal of Fisheries and Aquatic Sciences 43, 1935-1945.

Green B., Perschbacher P. \& Ludwig G. (2009) Effect of threadfin shad as forage for channel catfish fed daily or every third day. North American Journal of Aquaculture 71, $46-51$.

Guest W.C., Drenner R.W.,Threlkeld S.T., Martin F.D. \& Smith J.D. (1990) Effects of gizzard shad and threadfin shad on zooplankton and young-of-year white crappie production. Transactions of the American Fisheries Society 119 , 529-536.

Hansson L.-A., Annadotter H., Bergman E., Hamrin S.F., Jeppesen E., Kairesalo T., Luokkanen E., Nilsson P.-A., Søndergaard M. \& Strand J. (1998) Biomanipulation as an application of food-chain theory: constraints, synthesis, and recommendations for temperate lakes. Ecosystems 1, 558-574.

Hargreaves J.A. \& Steeby J.A. (1999) Factors affecting metabolism of commercial channel catfish ponds as indicated by continuous dissolved oxygen measurement. Journal of the World Aquaculture Society 30, 410-421.

Hariyadi S.,Tucker C.S., Steeby J.A., van der Ploeg M. \& Boyd C.E. (1994) Environmental conditions and channel catfish Ictalurus punctatus production under similar pond management regimes in Alabama and Mississippi. Journal of the World Aquaculture Society 25, 236-249.

Kuklinski K.E. (2006) Prolonged spawning of adult threadfin shad and contribution of age-0 threadfin shad as a brood source of summer larval presence in Hugo Reservoir, Oklahoma. In: Proceedings of the Sixtieth Annual Conference (ed. by A.G. Eversole), pp. 194-199. Southeastern Association of Game and Fish Commissioners, Tallahassee, FL, USA.

Lammens E.H.R.R., Gulati R.D., Meijer M.-L. \& van Donk E. (1990) The first biomanipulation conference: a synthesis. Hydrobiologia 200/201, 619-627.

Lazzaro X., Drenner R.W., Stein R.A. \& Smith J.D. (1992) Planktivores and plankton dynamics: effects of fish biomass and planktivore type. Canadian Journal of Fisheries and Aquatic Sciences 49, 1466-1473.

Lloyd S.W. \& Tucker C.S. (1988) Comparison of three solvent systems for extraction of chlorophyll $a$ from fish pond phytoplankton communities. Journal of the World Aquaculture Society 19, 36-40.

Lo Giudice G.M., Bayne D.R. \& Popma T.J. (2004) Threadfin shad Dorosoma petenense effects on water quality, phyto- 
plankton, and channel catfish production in ponds. Journal of the World Aquaculture Society 35, 345-356.

Ludwig G.M., Stone N.M. \& Collins C. (1998) Fertilization of Fish Fry Ponds. Publication Number 469. Southern Regional Aquaculture Center, Delta Research and Extension Center, Mississippi State University, Stoneville, MS, USA.

McQueen D.J., Post J.R. \& Mills E.L. (1986) Trophic relationships in freshwater pelagic ecosystems. Canadian Journal of Fisheries and Aquatic Sciences 43, 1571-1581.

Paerl H.W. (1988) Nuisance phytoplankton blooms in coastal, estuarine, and inland waters. Limnology and Oceanography 33, 823-847.

Paerl H.W. \& Tucker C.S. (1995) Ecology of blue-green algae in aquaculture ponds. Journal of the World Aquaculture Society 26, 109-131.

Ramcharan C.W., France R.L. \& McQueen D.J. (1996) Multiple effects of planktivorous fish on algae through pelagic trophic cascade. Canadian Journal of Fisheries and Aquatic Sciences 53, 2819-2828.

Shapiro J., Lamarra V. \& Lynch M. (1975) Biomanipulation: an ecosystem approach to lake restoration. In: Proceedings of a Symposium onWater Quality Management Through Biological Control (ed. by P.L. Brezonik \& J.L. Fox), pp. 85-96. University of Florida, Gainesville, FL, USA.

Sierp M.T., Qin J.G. \& Recknagel F. (2009) Biomanipulation: a review of biological control measures in eutrophic waters and the potential for Murray cod Maccullochella peelii peelii to promote water quality in temperate Australia. Reviews in Fish Biology and Fisheries 19, 143-165.

Smith D.W. (1988) Phytoplankton and catfish culture: a review. Aquaculture 74, 167-189.
Swingle H.A. (1969) Production of the threadfin shad, Dorosoma petenense (Günther). In: Proceedings of the TwentyThird Annual Conference (ed. by J.W. Webb), pp. 407-421. Southeastern Association of Game and Fish Commissioners, Columbia, SC, USA.

Torrans E.L. (2008) Production responses of channel catfish to minimum daily dissolved oxygen concentration in earthen ponds. North American Journal of Aquaculture $\mathbf{7 0}$, 371-381.

Torrans E.L. \& Lowell F. (1987) Effects of blue tilapia/channel catfish polyculture on production, food conversion, water quality and channel catfish off-flavor. Proceedings Arkansas Academy of Science 41, 82-86.

Tucker C.S. \& Lloyd S.W. (1984) Phytoplankton communities in channel catfish ponds. Hydrobiologia 112 , 137-141.

Tucker C.S. \& van der Ploeg M. (1993) Seasonal changes in water quality in commercial channel catfish ponds in Mississippi. Journal of the World Aquaculture Society 24, 473-481.

Tucker C.S., Hanson T.R. \& Kingsbury S.K. (2001) Management of off-flavors in pond-cultured channel catfish with weekly applications of copper sulfate. North American Journal of Aquaculture 63, 118-130.

van der Ploeg M. \& Tucker C.S. (1993) Seasonal trends in flavor quality of channel catfish, Ictalurus punctatus, from commercial ponds in Mississippi. Journal of Applied Aquaculture 3, 121-140.

Zimba P.., Tucker C.S., Mischke C.C. \& Grimm C.C. (2002) Short-term effect of diuron on catfish pond ecology. North American Journal of Aquaculture 64, 16-23. 